\title{
KOMUNIKASI TERAPEUTIK PADA LANSIA DI PANTI SOSIAL TRESNA WERDHA BUDI LUHUR JAMBI
}

\author{
Faridah $^{1}$, Iin Indrawati ${ }^{2}$ \\ ${ }^{1,2}$ Prodi DIII Keperawatan, STIKes Baiturrahim Jambi \\ Email: faridah_rty@yahoo.co.id
}

\begin{abstract}
Communication is a basic element of human interaction that allows one to establish, maintain and improve contracts with others because communication is done by someone, every day people often mistakenly think that communication is easy. But actually it is a complex process that involves behavior and relationships and allows individuals to associate with others and with their surroundings.As an effort to improve elderly health, it is necessary to continuously provide information to scientists, both individuals and groups so that the elderly can change from not knowing to knowing that the elderly can live healthy and productive lives, but with limited physical, psychological and mental needs approaches and methods so that messages are delivered more effectively.The method carried out on the elderly in providing information about the Healthy Lifestyle for the Elderly and the importance of eating fruit and vegetables through the approach of "therapeutic communication in the elderly". This activity was held on December 2018.The results are elements of a conducive situation, knowledge of the elderly, elderly attitudes towards the implementation of counseling, messages conveyed verbally and written after counseling with the therapeutic communication approach of the elderly, easier to understand the counseling material provided.The reduced understanding of the elderly in receiving information provided by the PSTW or the community is due to the reduced ability to listen to the elderly in providing counseling to improve the counseling method for the elderly so as not to be monotonous, so that the elderly easily understand the health information provided
\end{abstract}

Keywords: Therapeutic Communication, Elderly

\begin{abstract}
ABSTRAK
Komunikasi merupakan elemen dasar dari interaksi manusia yang memungkinkan seseorang untuk menetapkan, mempertahankan dan meningkatkan kontrak dengan orang lain karena komunikasi dilakukan oleh seseorang, setiap hari orang seringkali salah berpikir bahwa komunikasi adalah sesuatu yang mudah. Namun sebenarnya adalah proses yang kompleks yang melibatkan tingkah laku dan hubungan serta memungkinkan individu berasosiasi dengan orang lain dan dengan lingkungan sekitarnya. Sebagai upaya untuk meningkatkan kesehatan lanjut usia diperlukan pemberian informasi kepada ilansia baik individu maupunn kelompok secara terus-menerus agar lansia tersebut berubah dari tidak tahu menjadi tahu agar lansia dapat hidup sehat dan produktif, namun dengan keterbatasan lansia baik dari fisik, psikologis dan mentalnya maka diperlukan pendekatan dan metode agar pesan yang disampaikan lebih efektif. Metoda yang dilakukan pada lansia dalam pemberian informasi tentang Pola Hidup Sehat pada Lansia dan pentingnya makan buah dan sayur melalui pendekatan "komunikasi terapeutik pada lansia". Kegiatan ini dilaksanakan pada bulan Desember 2018. Hasil pada unsur situasi yang kondusif, pengetahuan lanjut usia, sikap lanjut usia terhadap pelaksanaan penyuluhan, pesan yang disampaikan lisan dan tulisan setelah dilakukan penyuluhan dengan pendekatan komunikasi terapeutik lansia lebih mudah memahami materi penyuluhan yang diberikan. Berkurangnya pemahaman lansia dalam menerima informasi yang diberikan oleh pihak PSTW atau masyarakat disebabkan berkurangya kemampuan mendengar lansia untuk itu dalam memberikan penyuluhan agar membenahi metoda penyuluhan bagi lansia agar tidak monoton, lansia mudah mengerti informasi -informasi kesehatan yang diberikan.
\end{abstract}

Kata Kunci : Komunikasi Terapeutik; Lanjut Usia 


\section{PENDAHULUAN}

Kesehatan merupakan faktor yang penting untuk menjadikan penuaan yang positif. Oleh karenanya, menyiapkan petugas kesehatan dan masyarakat untuk memenuhi kebutuhan kelompok lansia seperti: pelatihan perawatan lansia; mencegah dan mengelola penyakit kronis dan penyakit tidak menular, merancang kebijakan pengaturan perawatan jangka panjang dan paliatif yang berkelanjutan bagi lansia dan mengembangkan pelayanan ramah -lansia menjadi sangat penting. (Kemenkes RI, 2012)

Kesehatan lansia yang baik difokuskan pada bagaimana upaya untuk dapat menambah usia dan memperpanjang kehidupan, sehingga memungkinkan mereka tidak hanya hidup lebih lama, tetapi juga dapat memperluas keterlibatannya secara aktif dalam semua kegiatan di masyarakat. Seiring dengan kecenderungan yang positif tersebut dalam arti meningkatnya kesehatan global, akan muncul tantangan khusus dalam bidang kesehatan pada abad ke-21 karena bertambahnya jumlah lansia. Berbagai dampak dari peningkatan jumlah lansia antara lain adalah masalah penyakit degeneratif yang sering menyertai para lansia, bersifat kronis dan multipatologis, serta dalam penanganannya memerlukan waktu lama dan membutuhkan biaya cukup besar (Kemenkes, RI, 2012)

Promosi kesehatan adalah upaya untuk meningkatkan kemampuan masyarakat melalui pembelajaran dari, oleh, untuk dan bersama masyarakat, agar mereka dapat menolong diri sendiri, serta mengembangkan kegiatan yang bersumber daya masyarakat, sesuai social budaya setempat dan didukung kebijakan public yang berwawasan kesehatan.

Komunikasi merupakan elemen dasar dari interaksi manusia yang memungkinkan seseorang untuk menetapkan, mempertahankan dan meningkatkan kontrak dengan orang lain karena komunikasi dilakukan oleh seseorang, setiap hari orang seringkali salah berpikir bahwa komunikasi adalah sesuatu yang mudah. Namun sebenarnya adalah proses yang kompleks yang melibatkan tingkah laku dan hubungan serta memungkinkan individu berasosiasi dengan orang lain dan dengan lingkungan sekitarnya. Hal itu merupakan peristiwa yang terus berlangsung secara dinamis yang maknanya dipacu dan ditransmisikan. Untuk memperbaiki interpretasi pasien terhadap pesan, perawat harus tidak terburu-buru dan mengurangi kebisingan dan distraksi. Kalimat yang jelas dan mudah dimengerti dipakai untuk menyampaikan pesan karena arti suatu kata sering kali telah lupa atau ada kesulitan dalam mengorganisasi dan mengekspresikan pikiran. Instruksi yang berurutan dan sederhana dapat dipakai untuk mengingatkan pasien dan sering sangat membantu. (Bruner \& Suddart, 2001).

Komunikasi adalah proses interpersonal yang melibatkan perubahan verbal dan non verbal dari informasi dan ide. Komunikasi mengacu tidak hanya pada isi tetapi juga pada perasaan dan emosi dimana individu menyampaikan hubungan ( Potter-Perry, 301 ). Komunikasi pada lansia membutuhkan perhatian khusus. Perawat harus waspada terhadap perubahan fisik, psikologi, emosi, dan sosial yang memperngaruhi pola komunikasi. Perubahan yang berhubungan dengan umur dalam sistem auditoris dapat mengakibatkan kerusakan pada pendengaran. Perubahan pada telinga bagian dalam dan telinga mengalangi proses pendengaran pada lansia sehingga tidak toleran teradap suara. Berdasarkan hal - hal tersebut kami menulis makalah ini yang berjudul " komunikasi terapiutik pada lansia ".

Pemerintah Provinsi jambi melalui Dinas Sosial Kependudukan dan pencacatan Sipil Provinsi jambi 
berdasarkan peraturan daerah (PERDA) No. 14 tahun 2008 tentang Organisasi dan tata kerja dinas daerah Provinsi Jambi dan PERGUB Provinsi Jambi No. 1 Tahun 2009 tentang Organisasi dan tata kerja Unit PelaksanaanTteknis Dinas (UPTD) dan Badan pada Dinas dan Badan Daerah Provinsi jambi. Salah satu Unit Pelaksanaan Teknis Daerah (UPTD) adalah Pansti Sosial Tresna Werdha (PSTW) Budi Luhur Jambi yang memberikan pelayanan dan pembinaan kepada pada lanjut usia yang terlantar di Provinsi jambi.

Permasalahan di panti Werdha Budi Luhur jambi sangat beragam mulai dari masalah psikis maupun fisik dan sosialnya. Permasalahan secara fisik pada lansia merupakan penurunan fungsi organ tubuh, misalnya Rematoid Arthritis, Cardiovaskuler, Hipertensi, sehingga membuat mereka tidak berdaya, namun ada juga beberapa lansia masih mampu melakukan kegiatan keterampilan yang mereka miliki walaupun daya ingat, penglihatan, pendengaran mereka sudah menurun.

Sebagai upaya untuk meningkatkan kesehatan lanjut usia diperlukan pemberian informasi kepada ilansia baik individu maupunn kelompok secara terus-menerus agar lansia tersebut berubah dari tidak tahu menjadi tahu agar lansia dapat hidup sehat dan produktif, namun dengan keterbatasan lansia baik dari fisik, psikologis dan mentalnya maka diperlukan pendekatan dan metode agar pesan yang disampaikan lebih efektif. Adapaun pendekatan yang dilakukan pada lansia dalam pemberian informasi tentang peningkatan kesehatan adalah melalui "komunikasi terapeutik pada lansia".

komunikasi terapeutik adalah komunikasi yang direncanakan secara sadar, bertujuan dan kegiatannya dipusatkan untuk kesembuhan pasien (Indrawati, 2003). Komunikasi dengan lansia harus memperhatikan faktor fisik, psikologi, (lingkungan dalam situasi individu harus mengaplikasikan ketrampilan komunikasi yang tepat. disamping itu juga memerlukan pemikiran penuh serta memperhatikan waktu yang tepat.

Agar lansiatetap sehat dan produktif perlu dilakukan kebijakan tentang memomosikan kesehatan dalam setiap siklus kehidupan,, menciptakan lingkungan ramah lansia yang mendorong kesehatan dan partisipasi aktif lansia, menyediakan layanan kesehatan yang ramah lansia, meniingkatkan peran serta lansia dalam pembuatan kebijakan publik ramah lansia, mempertimbangkan pandangan lansia dalam setiap pengambilan keputusan dalam pembangunan di setiap tingkatan., menyadari nilai kearifan lansia dan bantu mereka berpartisipasi dalam keluarga dan masyarakat

\section{TARGET DAN LUARAN}

Program pengabdian masyarakat ini sasarannya adalah lanjut usia PSTW Budi Luhur Jambi yang di kategorikan Mengalami kemunduran secara fisik khususnya yang mengalami masalah pendengaran.

Target dan luaran tercapai setelah pelaksanaan pengabdian masyarakat ini $60 \%$ lanjut usia di PSTW Budi Luhur Jambi mampu memahami informasi secara umum khususnya masalah kesehatan .

Luaran yang ditargetkan dari pada pengabdian masayarakat ini adalah booklet pola hidup sehat lansia dan pentingnya makan sayur dan buah pada lansia, Modul mata kuliah keperawatan gerontonik dan mata kuliah komunikasi keperawatan

\section{METODE PELAKSANAAN}

Metode pelaksanaan yang dilakukan dengan cara penyuluhan dengan pendekatan komunikasi terapeutik pada lansia di PSTW Budi Luhur Jambi

Kegiatan ini dilaksanakan pada bulan Desember 2018, lokasi kegiatan 
dilaksanakan di Panti Sosial Tresna Werdha Jambi.

\section{HASIL DAN PEMBAHASAN}

Kegiatan Pengabdian masyarakat dengan melakukan penyuluhan dengan pendekatan komuikasi terapeutik. Peserta yang mengikuti kegiatan ini sebanyak 15 orang lansia PSTW Budi Luhur Jambi yang dibagi 2 kelompok.

Komunikasi terapeutik mengarah pada bentuk komunikasi interpersonal. Pace (1979) dalam Cangara (2012) mengemukakan bahwa komunikasi antarpribadi atau interpersonal communication merupakan proses komunikasi yang berlangsung antara dua orang atau lebih secara tatap muka di mana pengirim dapat menyampaikan pesan secara langsung dan penerima pesan dapat menerima dan menanggapi secara langsung. Komunikasi interpersonal merupakan komunikasi yang pesannya dikemas dalam bentuk verbal dan non verbal, seperti komunikasi pada umumnya komunikasi interpersonal selalu mencakup dua unsur pokok, yaitu isi pesan dan bagaimana isi pesan dikatakan atau dilakukan secara verbal atau nonverbal. Dua unsur tersebut sebaiknya diperhatikan dan dilakukan berdasarkan pertimbangan situasi, kondisi dan keadaan penerima pesan.

Selain hal tersebut, komunikasi sosial sangat mendukung bagi komunikasi terapeutik bagi pasien lansia

Mulyana(2009) menyebutkan fungsi pertama dari komunikasi terepeutik yang baik yaitu komunikasi sosia. Fungsi komunikasi sebagai komunikasi sosial setidaknya mengisyaratkan bahwa komunikasi penting untuk membangun konsep-konsep diri, aktualisasi diri, untuk kelangsungan hidup, untuk kebahagiaan, terhindar dari tekakanan dan ketegangan antara lain lewat komunikasi yang menghibur dan memupuk hubungan dengan orang lain. Fungsi komunikasi sosial ini harus dapat diterapkan dengan baik di lingkungan panti werdha mengingat semakin tuanya seseorang banyak terjadi kemunduran fisik atau bahkan tidak berfungsi dengan baik khusunya masalah pendengaran.

Ketika berkomunikasi dengan lansia dengan gangguan pendengaran, tataplah pasien sehingga pasien dapat membaca bibir dan menggunakan isyarat mata. Meminimalkan kebisingan, dan berbicara pelan, jelas dan dalam nada yang normal. Berteriak akan menghambat komunikasi, mengubah nada berfrekuensi tinggi dan mempersulit lansia memahami kata-kata pemberi pesan.

Ketika berkomunikasi dengan pasien dengan gangguan penglihatan, lingkungan dapat diperbaiki dengan memperbanyak pencahayaan, menggunakan warna-warna kontras untuk membuat objek lebih jelas dan menggunakan huruf yang besar serta berwarna kontras untuk setiap tanda. Setiap bahan dengan tulisan harus dicetak paling tidak dengan hurup berukuran 14 diatas kertas berwarna.

Peran perawat dalam usaha berkomunikasi harus memiliki pengetahuan, ketulusan, semangat dan praktik yang cukup sehingga memudahkan dalam melaksanakan tugasnya setiap hari

Menurut Stuart dan Sudeen dalam Taufik (2010) menjelaskan bahwa dalam proses komunikasi terapeutik terbagi menjadi empat tahapan, yaitu tahap persiapan atau tahap pra-interaksi, tahap perkenalan atau orientasi, tahap kerja, tahap terminasi

(1) Tahap pra-interaksi, pada tahap pra interaksi, perawat sebagai komunikator yang melaksanakan komunikasi terapeutik mempersiapkan dirinya untuk bertemu dengan lansia. Sebelum bertemu dengan lansia, perawat haruslah mengetahui beberapa informasi mengenai pasien, baik berupa nama, umur, jenis kelamin, keluhan penyakit, dan sebagainya. Apabila perawat telah dapat memersiapkan diri dengan baik sebelum bertemu dengan pasien, maka ia akan bisa menyesuaikan cara yang paing tepat dalam menyampaikan komunikasi terapeutik kepada lansia. 
(2) Tahap perkenalan atau tahap orientasi pada tahap ini antara perawat dengan lansia di PSTW Budi Luhur Jambi mempunyai kualitas yang cukup baik dalam hal kehangatan dan keterbukaan satu sama lain, seperti menceritakan tentang konsi keluarganya saat ini, hobinya apa saja, cerita tentang masa mudanya, dan lain-lain

(3) Tahap kerja atau sering disebut tahap lanjutan adalah tahap pengenalan lebih lanjutan adalah tahap pengenalan lebih jauh. Secara psikologis komunikasi yang bersifat terapeutik akan membuat lansia lebih nyaman. Berdasarkan observasi dilapangan penulis melihat bahwa lansia yang telah dilakukan penyuluhan dengan pendekatan komunikasi terapeutik lebih memahami materi yang disampaikan.

(4) Tahap terminasi, pada tahap ini terjadi pengikatan anat pribadi yang lebih jauh. Pasien lansia di tahapan ini merasa pada akhirnya "cukup dekat" dengan para perawat, bahkan menganggap seperti keluarga sendiri.

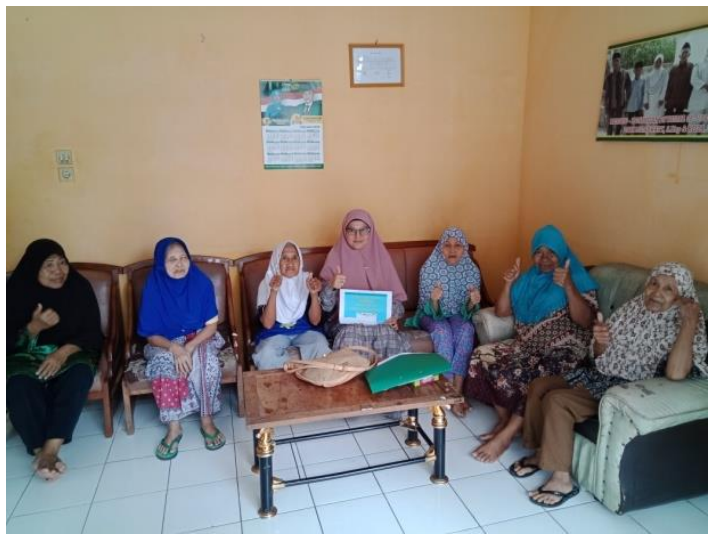

\section{KESIMPULAN DAN SARAN}

\section{Kesimpulan}

Kesehatan yang optimal pada pasien lanjut usia tidak hanya tergantung dari kebutuhan biomedis semata namun juga bergantung kepada kondisi sekitarnya seperti perhatian yang lebih terhadap keadaan sosialnya, ekonomi, kultural, psikologis. Hubungan saling memberi dan menerima antara perawat dan lansia dalam pelayanan keperawatan disebut komunikasi terapeutik perawat yang merupakan komunikasi profesional perawat. Komunikasi antara perawat dengan lansia harus efektif karena berpengaruh terhadap kesehatan lansia. Komunikasi terapeutik merupakan komunikasi yang direncanakan secara sadar, bertujuan dan dipusatkan untuk kesembuhan pasien.

\section{Saran}

Disarankan kepada Petugas panti hendaknya dalam memberikan penyuluhan agar membenahi metoda penyuluhan kepada lansia agar tidak monoton, sehingga lansia mudah mengerti informasi -informasi kesehatan yang diberikan.

\section{UCAPAN TERIMAKASIH}

Pengabdian masyarakat ini dapat terwujud dan selesai dengan baik karena adanyabantuan dari berbagai macam pihak maka dari itu penulis mengucapkan terima kasih kepada Ketua STIKES Baiturrahim Jambi, Kaprodi D-III keperawatan STIKES Baiturrahim Jambi, pimpinan PSTW Budi Luhur Jambi yang telah memfasilitasi kegiatan pengabdian masyarakat ini.

\section{DAFTAR PUSTAKA}

Bruner \& Suddart, 2001. Komunikasi Terapeutik Teori dan Praktik. Jakarta. EGC

Cangara, Hafied (2012). Pengantar Ilmu Komunikasi. Jakarta: PT Raja Grafindo Persada.

Kemenkes RI, 2012 Kesehatan Lanjut Usia. Jakarta

Mulyana , Deddy (2009). Ilmu Komunikasi Suatu Pengantar, Bandung Remaja. Rosdakarya

PERDA No. 14 tahun 2008. Tentang Organisasi dan tata kerja dinas daerah Provinsi Jambi

PERGUB Provinsi Jambi No. 1 Tahun 2009 tentang Organisasi dan tata kerja Unit PelaksanaanTteknis Dinas 
Jurnal Abdimas Kesehatan (JAK) Vol 1,No.2, Juni 2019 p-ISSN: 2655-9266 e-ISSN: 2655-9218

(UPTD) dan Badan pada Dinas dan

Badan Daerah Provinsi jambi 